\title{
Regulation of Glucosyl- and Fructosyltransferase Synthesis by Continuous Cultures of Streptococcus mutans
}

\author{
By D. G. WENHAM, T. D. HENNESSEY* AND J. A. COLE \\ Department of Biochemistry, University of Birmingham, Birmingham B15 2TT \\ * Imperial Chemical Industries Ltd, Pharmaceuticals Division, Mereside, \\ Alderley Park, Macclesfield SK10 4TG
}

(Received 19 February 1979)

\begin{abstract}
Streptococcus mutans strain Ingbritt, and its derivative B7 which had been passaged through monkeys, have been used to investigate how the synthesis of extracellular glucosyl- and fructosyltransferases is regulated. The most active enzyme from carbon-limited continuous cultures was a fructosyltransferase; enzymes catalysing the formation of water-insoluble glucans from sucrose were relatively inactive. Dextransucrase (EC 2.4.1.5), which catalyses soluble glucan synthesis, was most active in the supernatant fluid from cultures grown with excess glucose, fructose or sucrose, but full activity was detected only when the enzyme was incubated with both sucrose and dextran. Little dextransucrase activity was detected in carbon-limited cultures. It is concluded that glucosyl- and fructosyltransferases are constitutive enzymes in that they are synthesized at similar rates during growth with an excess of the substrate or of the products of the reactions which they catalyse. Although the Ingbritt strain was originally isolated from a carious lesion, it is now a poor source of glucosyltransferase activity. Glucosyltransferases were extremely active in cultures of a recent clinical isolate, strain 3209 , and were apparently induced during growth with excess glucose.
\end{abstract}

\section{INTRODUCTION}

Streptococci in dental plaque secrete enzymes which catalyse the synthesis of polysaccharides from sucrose. These polysaccharides are major structural components of the plaque matrix within which acidic products of bacterial metabolism accumulate (Gibbons et al., 1966; Cole, 1977). The fundamental question of how many different proteins are involved in plaque polysaccharide synthesis remains unanswered, but structural analyses of polymers produced by enzymes from Streptococcus mutans have revealed three types a water-soluble glucan, an insoluble glucan and a fructan (Baird et al., 1973). A high proportion of the glucose residues in the soluble glucan are linked by $(1 \rightarrow 6)-\alpha$ glycosidic bonds, so although other bond types are also present, the enzyme catalysing soluble glucan synthesis is considered to be a dextransucrase (EC 2.4.1.5). A major polysaccharide component of some dental plaques is a water-insoluble glucan or 'mutan'. The ability to synthesize this sticky polymer appears to be one of the major determinants of the cariogenicity of $S$. mutans strains (De Stoppelaar et al., 1971; Guggenheim et al., 1972; Nalbandian et al., 1974; Gibbons \& van Houte, 1975; Hojo et al., 1976; Montville et al., 1977; Koga \& Inoue, 1978). Mutan contains a majority of $(1 \rightarrow 3)-\alpha$ glycosidic linkages formed from sucrose by the action of a second glucosyltransferase which will be referred to as 'mutansucrase'. The fructan contains $(2 \rightarrow 1)-\beta$ links and is formed as the result of fructosyltransferase activity (Baird et al., 1973). Our primary aim was to determine how nutritional factors, such as the identity of the carbon source and the growth-limiting nutrient, 
regulate the rates of synthesis of these enzymes by continuous cultures of $S$. mutans. The three strains used were all originally isolated from carious lesions in humans: their serotype, $c$, is typical of strains most frequently found in Western man (Keene et al., 1977).

Despite recent interest in the purification and properties of glucosyltransferases and in their role in dental caries, there is little reliable information about how nutritional factors regulate their rates of synthesis. Several research groups have measured glucosyltransferase activities of batch cultures of $S$. mutans and $S$. sanguis during growth with various fermentable carbohydrates, and the effect of the carbon source on the distribution of the enzyme between extracellular and cell-associated proteins has been determined (McCabe \& Smith, 1973; Chassy et al., 1976; Janda \& Kuramitsu, 1976, 1978; Beeley \& Black, 1977; Montville et al., 1977; Hamada \& Torii, 1978). It was concluded that glucosyltransferases are constitutive enzymes which are synthesized only during the exponential phase of growth: however, under these conditions all nutrients are available in excess, so it was impossible to determine how rates of enzyme synthesis vary with changes in the growth-limiting nutrients. Furthermore, information about the regulation of rates of protein synthesis cannot be obtained from activity measurements unless the assay is specific and able to detect both active and inactive forms of the enzyme. The extracellular glucosyltransferases of many streptococci are contaminated with invertase and fructosyltransferase and are fully active only when assayed with dextran (Fukui et al., 1974; Germaine et al., 1974; Chassy et al., 1976; Burckhardt \& Guggenheim, 1976; Ellwood et al., 1976; Schachtele et al., 1976; Ciardi et al., 1977; Montville et al., 1977). It is unlikely that these essential criteria have been fulfilled in most of the previous studies. We have therefore grown three strains of $S$. mutans in continuous culture with a growth-limiting supply, or an excess, of carbohydrate and determined the relative activities of glucosyl- and fructosyltransferases both in the presence and absence of added dextran.

\section{METHODS}

Organisms and media. Streptococcus mutans strain Ingbritt was obtained from J. M. Hardie, The London Hospital Medical College, London E1. Strain Ingbritt B7 is a derivative of the Ingbritt strain which was re-isolated after passage through monkeys: it was obtained as a freeze-dried culture from D. C. Ellwood, Microbiological Research Establishment, Porton Down, Wiltshire. Strain 3209 was isolated in December 1977 by Miss D. A. Sidaway from the dentine of a carious fissure in a permanent tooth of a patient in the Birmingham Dental Hospital. The serotype, $c$, was determined by Dr. R. R. B. Russell, The Royal College of Surgeons of England Research Establishment, Downe, Kent. Pure cultures of each strain were able to ferment mannitol, sorbitol and raffinose, were catalase-negative and formed a characteristic range of colony types on mitis-salivarius agar and on horse blood agar.

Stock cultures were maintained on horse blood agar and were subcultured every $14 \mathrm{~d}$. Fresh cultures of the Ingbritt strains were generated from freeze-dried ampoules approximately every 3 months.

Culture conditions, yields and sample preparation. Bacteria were grown in continuous culture in $840 \mathrm{ml}$ of medium, contained in a 1.51 fermentation vessel (L. H. Engineering, Stoke Poges, Bucks.), at $37^{\circ} \mathrm{C}$ and $\mathrm{pH} 6.5 \pm 0 \cdot 1$. The dilution rate was $0 \cdot 12 \pm 0.01 \mathrm{~h}^{-1}$ (unless otherwise stated). A slow stream of $\mathrm{N}_{2} / \mathrm{CO}_{2}$ $(95: 5, \mathrm{v} / \mathrm{v})$ was passed through the culture to keep it anaerobic. The culture medium contained (per 1 distilled

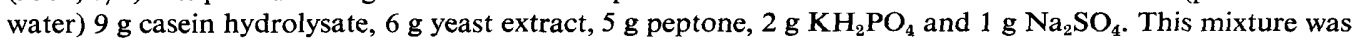
autoclaved in 8 or 161 batches at $124^{\circ} \mathrm{C}$ for 40 or $60 \mathrm{~min}$, and then sterile carbon source was added to the concentration stated in the text. Inocula for the fermenter were grown for $20 \mathrm{~h} \mathrm{at} 37^{\circ} \mathrm{C}$ in $20 \mathrm{ml} \mathrm{Lennox}$ (1955) broth, supplemented with $4 \mathrm{~g}$ glucose $1^{-1}$, in an unshaken $150 \mathrm{ml}$ conical flask.

When 4 to 61 of medium had flowed through the fermenter and the culture turbidity (determined at $650 \mathrm{~nm}$ ) was constant, a $250 \mathrm{ml}$ sample was taken directly from the vessel, cooled to $4{ }^{\circ} \mathrm{C}$ and centrifuged for $5 \mathrm{~min}$ at $10000 \mathrm{~g}$. Part of the supernatant solution was stored at $-20^{\circ} \mathrm{C}$ for subsequent chemical analyses, and another part was assayed within $4 \mathrm{~h}$ for glucosyl- and fructosyltransferase activities. Activities of enzymes bound to the cell surface were determined with bacteria which had been harvested by centrifugation from $25 \mathrm{ml}$ culture and resuspended in $15 \mathrm{ml} 0 \cdot 1 \mathrm{M}$-sodium acetate, $\mathrm{pH} \mathrm{6.0.} \mathrm{To} \mathrm{determine} \mathrm{cell} \mathrm{yields,} \mathrm{bacteria} \mathrm{from}$ $100 \mathrm{ml}$ culture were collected by centrifugation for $5 \mathrm{~min}$ at $10000 \mathrm{~g}$, resuspended in $20 \mathrm{ml}$ water, collected by centrifugation again and resuspended in $25 \mathrm{ml}$ water. The dry weight was determined by heating $3 \times 4 \mathrm{ml}$ samples at $105^{\circ} \mathrm{C}$ until constant weight was achieved. 
Enzyme assays and determination of hexose concentration. In a typical assay, $1 \mathrm{ml}$ of the culture supernatant or the washed bacterial suspension was incubated with $0.5 \mathrm{ml} 0.1 \mathrm{M}$-sodium acetate, $\mathrm{pH} 6.0$ ('acetate buffer') and $0.5 \mathrm{ml} 20 \%(\mathrm{w} / \mathrm{v})$ sucrose solution in four sets of tubes for $2 \mathrm{~h}$ at $37^{\circ} \mathrm{C}$. Each of the four sets of tubes was duplicated. To one set, which was used to estimate the total rate of polysaccharide synthesis, $8 \mathrm{ml}$ methanol was added. Glucans and fructans are insoluble in $80 \%(\mathrm{v} / \mathrm{v})$ methanol, providing that sufficient time at $4{ }^{\circ} \mathrm{C}$ is allowed for complete precipitation, and both types of polymer give a positive reaction in the phenol-sulphuric acid assay (see below). After at least $50 \mathrm{~min}$ at $4{ }^{\circ} \mathrm{C}$, the precipitated polysaccharide was collected by centrifugation for $10 \mathrm{~min}$ at $4000 \mathrm{~g}$. The supernatant was discarded and the pellet was resuspended in $1 \mathrm{ml}$ acetate buffer. Polysaccharides were reprecipitated three times by $80 \%$ (v/v) methanol, collected by centrifugation and resuspended in $1 \mathrm{ml}$ acetate buffer after the second and third washing cycles or dissolved in $4.0 \mathrm{ml} 1 \mathrm{M}-\mathrm{NaOH}$ after the fourth wash.

The second set of tubes was used to determine the mutansucrase activity: $0.2 \mathrm{ml} \mathrm{10 \% (w/v)} \mathrm{trichloroacetic}$ acid was added after incubation with sucrose and tubes were immediately cooled to $4{ }^{\circ} \mathrm{C}$. After at least $50 \mathrm{~min}, 5 \mathrm{ml}$ water was added and insoluble polysaccharide was collected by centrifugation for $10 \mathrm{~min}$ at $4000 \mathrm{~g}$. The supernatant was discarded and the pellet was washed three times by alternate resuspension in $5 \mathrm{ml}$ water and centrifugation. The final mutan pellet was dissolved in $1 \mathrm{ml} 1 \mathrm{M}-\mathrm{NaOH}$.

The effect of dextran on enzyme activity was determined with two further sets of tubes which contained $0.3 \mathrm{ml}$ acetate buffer and $0.2 \mathrm{ml} 0.06 \%(\mathrm{w} / \mathrm{v})$ dextran instead of $0.5 \mathrm{ml}$ acetate buffer.

The hexose concentration of the solutions of mutan and total polysaccharides was determined by the phenol-sulphuric acid method of Dubois et al. (1956). Duplicate 50 and $100 \mu \mathrm{g}$ glucose and triplicate $100 \mu \mathrm{g}$ fructose samples were included as internal standards, and results were expressed as glucose equivalents. Glucose duplicates were reproducible to within $2 \%$, but the standard deviation for fructose replicates was $4 \%$. The ketohexose concentration of these solutions was estimated by the method of Kulka (1956) with $100 \mu \mathrm{g}$ fructose as the internal standard: duplicates were reproducible to within $1 \%$. No colour developed when fructose was replaced by glucose, dextran or insoluble glucan. The quantity of polysaccharide precipitated in samples which were incubated without sucrose was subtracted from that in test samples. The dextransucrase activity, $D$, was calculated from the expression

$$
D=T-[M+F \times(S F / S G)]
$$

in which $T$ and $M$ are the total polysaccharide and mutan as estimated by the phenol-sulphuric acid method; $S F$ and $S G$ are the absorbances at $490 \mathrm{~nm}$ of $100 \mu \mathrm{g}$ samples of fructose and glucose in the phenol-sulphuric acid assay; and $F$ is the fructan formed as estimated by the ketohexose assay. Thus, $F \times(S F / S G)$ represents the contribution of fructans to the colour intensity developed in the phenol-sulphuric acid assay for total polysaccharides (Dubois et al., 1956).

Reproducibility of the data. The greatest difference between two independent assays of the rate of mutan synthesis by a single enzyme sample from the Ingbritt strains was $3 \mu \mathrm{g}$ glucose from sucrose polymerized $\mathrm{h}^{-1} \mathrm{ml}^{-1}$, and duplicated fructosyltransferase assays agreed to within $3 \%$. Errors due to loss of polysaccharide during precipitation, centrifugation and resuspension were therefore very small. Control experiments established that, under the specified conditions, less polysaccharide was precipitated by ethanol than by methanol and replicates were also far less reproducible: methanol is routinely used in other laboratories to precipitate polysaccharides quantitatively (Chludzinski et al., 1974; Janda \& Kuramitsu, 1976; Robrish et al., 1972).

Dextransucrase estimations are subject to cumulative errors, but the major source was in the colour intensity contributed by fructans in the phenol-sulphuric acid assay (i.e. in $T$ and $S F$ in equation 1). Fructosyltransferase was often the most active extracellular enzyme in cultures of the Ingbritt strain, so the variance in the estimation of $D$ is approximately twice the variance of $F \times(S F / S G)$. The standard deviations are given for each dextransucrase assay.

Chemical estimations. Proteins were separated from interfering low molecular weight compounds by acidifying $9 \mathrm{ml}$ culture supernatant with $1 \mathrm{ml} 25 \%$ (w/v) metaphosphoric acid. After 20 min at $4{ }^{\circ} \mathrm{C}$, the precipitated protein was collected by centrifugation for $10 \mathrm{~min}$ at $33000 \mathrm{~g}$ and redissolved in $1 \mathrm{ml} 0 \cdot 2 \mathrm{M}-\mathrm{KOH}$. The protein concentration was then determined by Lowry's method. Glucose and fermentation products were determined as described by Dubowski (1962) and Keevil et al. (1979), respectively.

Chemicals. Dextran grade C (mol. wt range 60000 to 90000 ) was obtained from BDH. Components of bacterial culture media were obtained from Oxoid or Lab M, London. Methanol was standard laboratory reagent grade; all other chemicals were of the highest purity available. 
Table 1. Effect of glucose concentration on the fermentation products and cell yield of $S$. mutans strain Ingbritt during growth in continuous culture at a dilution rate of $0.043 \mathrm{~h}^{-1}$

\begin{tabular}{|c|c|c|c|c|}
\hline \multirow[b]{2}{*}{ Assay } & \multicolumn{4}{|c|}{ Glucose concn in feed medium $\left(\mathrm{g}^{-1}\right)$} \\
\hline & 6 & 13 & 26 & 36 \\
\hline Residual glucose in fermenter (mM) & $0 \cdot 76$ & $0 \cdot 34$ & 0.44 & 34 \\
\hline Glucose in feed (as assayed; $\mathrm{mm}$ ) & 34 & 77 & 144 & 234 \\
\hline Glucose utilized (\%) & $97 \cdot 7$ & $99 \cdot 5$ & $99 \cdot 7$ & $82 \cdot 0$ \\
\hline Cell yield ( $g$ dry wt $1^{-1}$ ) & 1.05 & 1.45 & $2 \cdot 57$ & $2 \cdot 15$ \\
\hline Ethanol in culture (mM) & $15 \cdot 4$ & $45 \cdot 8$ & $43 \cdot 5$ & $1 \cdot 0$ \\
\hline Acetate in culture (mM) & $56 \cdot 8$ & $39 \cdot 6$ & $50 \cdot 1$ & $8 \cdot 4$ \\
\hline Lactate in culture (mM) & $8 \cdot 4$ & $4 \cdot 3$ & $31 \cdot 3$ & $120 \cdot 8$ \\
\hline Succinate in culture (mM) & $0 \cdot 8$ & $0 \cdot 2$ & 0.4 & $1 \cdot 1$ \\
\hline
\end{tabular}

Table 2. Effect of carbon source during growth on the glucosyl-and fructosyltransferase activities of culture supernatants of $S$. mutans strain Ingbritt

Activities are expressed as $\mu \mathrm{g}$ polysaccharide formed $\mathrm{h}^{-1} \mathrm{ml}^{-1}$; standard deviations for dextransucrase assays are given in parentheses.

$\begin{array}{ccccc}\text { Dextran } & \begin{array}{c}\text { Mutan- } \\ \text { in } \\ \text { assay }\end{array} & \begin{array}{c}\text { sucrase } \\ \text { activity }\end{array} & \begin{array}{c}\text { Dextransucrase } \\ \text { activity }\end{array} & \begin{array}{c}\text { Fructosyl- } \\ \text { transferase } \\ \text { activity }\end{array} \\ \begin{array}{c}\text { Glucose-limited } \\ \left(6 \mathrm{~g} \mathrm{l}^{-1}\right)\end{array} & - & 4 & <40(43) & 770 \\ \text { Glucose-excess } & + & \text { ND } & 70(40) & 720 \\ \left(36 \mathrm{~g} \mathrm{l}^{-1}\right) & - & 18 & 40(14) & 250 \\ \text { Fructose-limited } & - & \text { ND } & 430(18) & 320 \\ \left(6 \mathrm{~g} \mathrm{l}^{-1}\right) & + & 5 & <30(21) & 390 \\ \text { Fructose-excess } & - & \text { ND } & 60(25) & 440 \\ \left(36 \mathrm{~g} \mathrm{l}^{-1}\right) & + & \text { ND } & 240(16) & 240 \\ \text { Sucrose-limited } & - & 29 & <30(42) & 760 \\ \left(6 \mathrm{~g} \mathrm{l}^{-1}\right) & + & 34 & <30(42) & 750 \\ \text { Sucrose-excess* } & - & 44 & * 140(<10) & 50 \\ \left(36 \mathrm{~g} \mathrm{l}^{-1}\right) & + & 48 & 140(<10) & 40\end{array}$

ND, Not determined, because it had previously been established that dextran has no significant effect on the rate of mutan synthesis.

* No steady state was achieved with excess sucrose, and the culture supernatant contained soluble glucan synthesized during growth.

\section{RESULTS}

Growth-limiting nutrient in continuous cultures with different concentrations of glucose

Steady states were established with $6,13,26$ or $36 \mathrm{~g}$ glucose $1^{-1}$ in the feed medium, and then the concentrations of the various fermentation products, residual glucose and the density of the culture were determined. A high concentration of glucose was detected in the fermentation vessel only with $36 \mathrm{~g}$ glucose $1^{-1}$ in the feed medium. During this steady state the major fermentation product was lactate, and little acetate and virtually no ethanol accumulated (Table 1). Conversely, little lactate accumulated during growth with 6 or $13 \mathrm{~g}$ glucose $1^{-1}$ in the feed, and ethanol and acetate were the major fermentation products (Table 1). The fermentation products and the effects of increasing the glucose concentration on the bacterial yield during growth with 6 or $36 \mathrm{~g} \mathrm{l}^{-1}$ were entirely consistent with data reported previously for cultures in which glucose was growth-limiting or in excess (Carlsson \& Griffith, 1974; Ellwood et al., 1974), so these concentrations of fermentable carbohydrate were used subsequently. 
Table 3. Effect of glucose concentration during growth on the rate of polysaccharide synthesis by extracellular proteins from $S$. mutans strain Ingbritt B7

Enzyme activities are expressed as $\mu \mathrm{g}$ polysaccharide formed $\mathrm{h}^{-1} \mathrm{ml}^{-1}$; standard deviations for dextransucrase assays are given in parentheses.

$\begin{array}{lccc} & \begin{array}{c}\text { Dextran } \\ \text { in } \\ \text { Assay }\end{array} & \overbrace{\begin{array}{c}\text { Glucose-limited } \\ \left(6 \mathrm{~g} \mathrm{l}^{-1}\right)\end{array}}^{\text {Growth condition }} & \begin{array}{c}\text { Glucose-excess } \\ \left(36 \mathrm{~g} \mathrm{l}^{-1}\right)\end{array} \\ \text { Dextransucrase } & - & <30(30) & 50(<10) \\ \text { Mutansucrase } & + & <30(33) & 280(<10) \\ \text { Fructosyltransferase } & - & 21 & 28 \\ & - & 520 & 120 \\ & + & 590 & 140\end{array}$

\section{Effect of carbon source on glucosyl- and fructosyltransferase synthesis}

Glucose and fructose are products of fructosyl- and glucosyltransferase activities when sucrose is the substrate, so the effects on enzyme synthesis of the availability of each of these compounds during growth were investigated. Clumps of polysaccharide accumulated in the culture when excess sucrose was supplied and bacteria adhered to the walls of the vessel and the $\mathrm{pH}$ electrodes: no steady-state was achieved, and three independent experiments were terminated at this point.

Rates of insoluble glucan synthesis by extracellular proteins varied little as the carbon source was changed from glucose to fructose or sucrose, or when the fermentable carbohydrate was growth-limiting or in excess (Table 2). In contrast, significant dextransucrase activities were detected in the spent culture only after growth with an excess of each of the carbohydrates. This dextransucrase activity was almost totally dependent upon dextran for activity and was an order of magnitude greater than the potential error in the assay method. If mutansucrase activity had been underestimated because of failure to sediment insoluble glucans, an appreciable concentration of 'soluble' glucan should have been detected in the absence of a dextran primer: this was not observed. Furthermore, little turbidity developed during the incubation of enzyme samples with sucrose. Conversely, the apparent increase in dextransucrase activity on addition of a primer dextran was not due to the conversion of mutansucrase into dextransucrase because the increase was an order of magnitude greater than the mutansucrase activity in the absence of primer (see Montville et al., 1977; Ciardi et al., 1977).

The increased rate of soluble glucan synthesis by cultures grown with excess carbohydrate might simply have reflected an increase in the concentration of biomass or extracellular protein in these cultures. However, when dextransucrase activities were expressed relative to each of these parameters, the conclusion that dextransucrase activities increased when excess carbohydrate was supplied was confirmed, irrespective of which baseline was selected for comparison.

Considerable variations in fructosyltransferase activities were observed with independent cultures, but this activity decreased two- to fourfold when excess glucose, fructose or sucrose was supplied to the corresponding carbon-limited culture (Table 2). Fructosyltransferase was by far the most active enzyme in all of the carbon-limited cultures.

Glucosyltransferase activity associated with the bacterial surface was low, and fructosyltransferase was far less active than in the culture supernatant (data not shown).

\section{Enzyme activities in cultures of $S$. mutans strain Ingbritt B7}

Ellwood et al. (1976) reported considerable variations in the types of polysaccharide formed by cultures of the Ingbritt strain received from different laboratories, so it was 
Table 4. Effect of glucose concentration during growth on the rates of polysaccharide synthesis by the recent clinical isolate $S$. mutans strain 3209

Two sets of data are given for each growth condition so that the reproducibility of independently established steady states can be assessed. Activities are expressed as $\mu \mathrm{g}$ polysaccharide formed $\mathrm{h}^{-1} \mathrm{ml}^{-1}$; standard deviations for dextransucrase assays are given in parentheses.

\begin{tabular}{|c|c|c|c|c|c|}
\hline \multirow{3}{*}{$\begin{array}{c}\text { Assay } \\
\text { Extracellular mutansucrase }\end{array}$} & \multirow{3}{*}{$\begin{array}{c}\text { Dextran in } \\
\text { assay } \\
- \\
+\end{array}$} & \multicolumn{4}{|c|}{ Growth condition } \\
\hline & & \multicolumn{2}{|c|}{$\begin{array}{l}\text { Glucose-limited } \\
\qquad\left(6 \mathrm{~g} \mathrm{l}^{-1}\right)\end{array}$} & \multicolumn{2}{|c|}{$\begin{array}{l}\text { Glucose-excess } \\
\quad\left(36 \mathrm{~g} \mathrm{l}^{-1}\right)\end{array}$} \\
\hline & & $\begin{array}{r}45 \\
113\end{array}$ & $\begin{array}{l}166 \\
200\end{array}$ & $\begin{array}{l}4440 \\
4220\end{array}$ & $\begin{array}{l}2980 \\
1350\end{array}$ \\
\hline Extracellular dextransucrase & $\overline{+}$ & $\begin{array}{l}118(11) \\
185(12)\end{array}$ & $\begin{array}{l}126(11) \\
149(10)\end{array}$ & $\begin{array}{r}350(13) \\
2080(30)\end{array}$ & $\begin{array}{r}356(20) \\
2230(28)\end{array}$ \\
\hline $\begin{array}{l}\text { Extracellular fructosyltransferase } \\
\text { (soluble fructan) }\end{array}$ & $\overline{+}$ & $\begin{array}{l}203 \\
217\end{array}$ & $\begin{array}{l}190 \\
160\end{array}$ & $\begin{array}{l}240 \\
537\end{array}$ & $\begin{array}{l}362 \\
495\end{array}$ \\
\hline $\begin{array}{l}\text { Extracellular fructosyltransferase } \\
\text { (insoluble fructan) }\end{array}$ & $\overline{+}$ & $\begin{array}{l}<10 \\
<10\end{array}$ & $\begin{array}{l}<10 \\
<10\end{array}$ & $\begin{array}{r}104 \\
84\end{array}$ & $\begin{array}{r}232 \\
78\end{array}$ \\
\hline Cell-associated glucosyltransferase & $\overrightarrow{+}$ & $\begin{array}{l}62 \\
78\end{array}$ & $\begin{array}{l}140 \\
101\end{array}$ & $\begin{array}{r}36 \\
117\end{array}$ & $\begin{array}{l}51 \\
40\end{array}$ \\
\hline Cell-associated fructosyltransferase & $\overline{+}$ & $\begin{array}{r}88 \\
130\end{array}$ & $\begin{array}{l}125 \\
130\end{array}$ & $\begin{array}{l}33 \\
42\end{array}$ & $\begin{array}{l}54 \\
32\end{array}$ \\
\hline
\end{tabular}

possible that the low rates of soluble and insoluble glucan synthesis reported above were due to sequential genetic losses which had occurred during maintenance on conventional laboratory media. Glucosyltransferases might be more active in cultures of strain Ingbritt B7 which has been maintained in, and re-isolated from, the more selective environment of a monkey's mouth. This strain was therefore grown with a limited supply or an excess of glucose, and extracellular glucosyl- and fructosyltransferase activities were determined. Fructosyltransferase was again the most active enzyme secreted by the glucose-limited culture, but its rate of synthesis was apparently repressed by excess glucose (Table 3 ). Mutansucrase was inactive in both types of culture, and although little dextransucrase activity was detected in the glucose-limited culture, a dextran-stimulated activity was readily detected when excess glucose was supplied (Table 3).

\section{Glucosyl-and fructosyltransferase activities of a recent clinical isolate of $S$. mutans}

Streptococcus mutans strain 3209 was grown in continuous culture within a week (two subcultures) of its isolation from carious dentine. Dextransucrase and mutansucrase activities were readily detected even during growth with limiting glucose but increased substantially when glucose was available in excess (Table 4). During growth with excess glucose, mutansucrase was up to 100 -fold more active than in the corresponding cultures of the Ingbritt strain and dextransucrase activity was again stimulated by dextran.

Fructosyltransferase was active in the glucose-limited culture but increased rather than decreased when excess glucose was supplied (Table 4). Extracellular proteins from cultures grown with excess glucose catalysed the synthesis of both soluble and insoluble fructans, but the quantity of insoluble fructan was small compared to the mutan with which it was associated.

Glucosyl- and fructosyltransferase activities associated with the cell surface were again less active than those in the extracellular fluid, especially during growth with excess glucose (Table 4). 


\section{DISCUSSION}

Although the Ingbritt strain of $S$. mutans is a poor source of glucosyltransferase activity (Tables 2 and 3), two conclusions can be drawn concerning the regulation of enzyme synthesis. Neither dextransucrase nor mutansucrase in this strain is regulated by catabolite repression, substrate induction or product repression, in that they are synthesized under all growth conditions and are thus constitutive enzymes. This conclusion also applies to strain 3209 which is a more prolific source of glucosyltransferase activity. Secondly, glucosyltransferase synthesis by all three strains is apparently induced during growth with an excess of a fermentable carbohydrate.

Only Ellwood \& Hunter (1976) have reported data concerning rates of polysaccharide synthesis by continuous cultures of $S$. mutans. These authors concluded that enzyme synthesis was apparently repressed when glucose was available in excess. Although this is inconsistent with our data, Ellwood \& Hunter (1976) did not state their assay conditions or the strain used. If dextran had been omitted during incubation of enzyme with sucrose, the majority of the dextransucrase activity would not have been detected (see Tables 2 to 4). Conversely, if only the phenol-sulphuric acid assay was used, the contribution of fructosyltransferase to the total rate of polysaccharide synthesis would be unknown. In our experiments, the only activity which decreased when excess carbohydrate was supplied to the Ingbritt strain was fructosyltransferase (Tables 2 and 3).

Although our conclusions are based on the assumption that the activity of an enzyme in the spent growth medium is directly proportional to its rate of synthesis, several lines of evidence suggest that this is justified. Janda \& Kuramitsu (1976) demonstrated that, during growth with glucose, the majority of the glucosyltransferase activity synthesized by $S$. mutans was secreted into the culture rather than retained in the cytoplasm or associated with the bacterial surface, but the latter conclusion would probably not apply during growth with sucrose (Gibbons \& Fitzgerald, 1969; Freedman \& Tanzer, 1974; Germaine \& Schachtele, 1976; Janda \& Kuramitsu, 1978). Experiments in this laboratory and elsewhere have also established that the staining intensity of certain protein bands after polyacrylamide gel electrophoresis can be correlated with the glucosyl- and fructosyltransferase activities (B. M. Newman, unpublished observations).

In view of the role postulated for insoluble polysaccharides in the development of dental caries, it was surprising that the Ingbritt strain, which was originally isolated from a carious lesion, produced little mutansucrase activity. Experiments are currently in progress to compare the glucosyl- and fructosyltransferase activities and cariogenicities of various strains in order to determine whether strain Ingbritt or 3209 is more typical of clinical isolates and whether there is a correlation between potential rates of mutan synthesis and cariogenicity.

We are grateful to Drs R. R. B. Russell, B. M. Newman, S. B. Mohan and M. Winter for extensive collaboration and for confirming the identity of the extracellular enzymes secreted by $S$. mutans. D.G.W. was supported by a Science Research Council Cooperative Award in Science and Engineering sponsored by Imperial Chemical Industries Limited, Pharmaceuticals Division, Macclesfield, Cheshire.

\section{REFERENCES}

Baird, J. K., Longyear, V. M. C. \& Ellwood, D. C. (1973). Water insoluble and soluble glucans produced by extracellular glycosyltransferases from Streptococcus mutans. Microbios 8, 143-150.

BeELeY, J. A. \& BLACK, P. M. (1977). Glucosyltransferase production by Streptococcus sanguis 804. Infection and Immunity 15, 50-58.
Burckhardt, J. J. \& Guggenheim, B. (1976). Interactions of antisera, sera and oral fluid with glucosyltransferases. Infection and Immunity 13, 1009-1022.

Carlsson, J. \& Griffith, C. J. (1974). Fermentation products and bacterial yields in glucose-limited and nitrogen-limited cultures of streptococci. Archives of Oral Biology 19, 1105-1109. 
Chassy, B. M., Beall, J. R., Bielawski, R. M., Porter, E. V. \& Donkersloot, J. A. (1976). Occurrence and distribution of sucrose-metabolizing enzymes in oral streptococci. Infection and Immunity 14, 408-415.

Chludzinski, A. M., Germaine, G. R. \& SchachTELE, C. F. (1974). Purification and properties of dextransucrase from Streptococcus mutans. Journal of Bacteriology 118, 1-7.

Ciardi, J. E., Beaman, A. J. \& Wittenberger, C. L. (1977). Purification, resolution and interaction of the glucosyltransferases of Streptococcus mutans 6715. Infection and Immunity 18, 237-246.

Cole, J. A. (1977). A biochemical approach to the control of dental caries. Biochemical Society Transactions 5, 1232-1239.

De Stoppelaar, J. D., Konig, K. G., Plasschaert, A. J. M. \& VAN DER HOEVEN, J. S. (1971). Decreased cariogenicity of a mutant of Streptococcus mutans. Archives of Oral Biology 16,971-975.

Dubois, M., Gilles, K. A., Hamilton, J. K., Rebers, P. A. \& SMith, F. (1956). Colorimetric method for determination of sugars and related substances. Analytical Chemistry 28, 350-356.

Dubowski, K. M. (1962). An $o$-toluidine method for body-fluid glucose determination. Clinical Chemistry 8, 215-235.

Ellwood, D. C. \& Hunter, J. R. (1976). The mouth as a chemostat. In Continuous Cultures: Application and New Fields, Proceedings of the 6th International Symposium on Continuous Culture of Micro-organisms, pp. 270-282. Edited by A. C. R. Dean, D. C. Ellwood, C. G. J. Evans and J. Melling. Chichester: Ellis Horwood.

Ellwood, D. C., Hunter, J. R. \& Longyear, V. M. C. (1974). Growth of Streptococcus mutans in a chemostat. Archives of Oral Biology 19, 659-664.

Ellwood, D. C., Baird, J. K., Hunter, J. R. \& LONGYEAR, V. M. C. (1976). Variations in surface polymers of Streptococcus mutans. Journal of Dental Research 55, C42-C49.

Freedman, M. L. \& TANZer, J. M. (1974). Dissociation of plaque formation from glucaninduced agglutination in mutants of Streptococcus mutans. Infection and Immunity 10, 189-196.

Fukui, K., Fukui, Y. \& Moriyama, T. (1974). Acceleration of dextransucrase activity of Streptococcus mutans by secretory immunoglobulin $\mathrm{A}$. Journal of Bacteriology 118, 804-809.

Germaine, G. R. \& Schachtele, C. F. (1976). Streptococcus mutans dextransucrase mode of interaction with high-molecular-weight dextran and role in cellular aggregation. Infection and Immunity 13, 365-372.

Germaine, G. R., Chludzinski, A. M. \& SchachTELE, C. F. (1974). Streptococcus mutans dextransucrase: requirement for primer dextran. Journal of Bacteriology 120, 287-294.

Gibbons, R. J. \& Fitzgerald, R. J. (1969). Dextraninduced agglutination of Streptococcus mutans and its potential role in the formation of microbial dental plaques. Journal of Bacteriology 98, 341-346.

GibBons, R. J. \& VAN Houte, J. (1975). Bacterial adherence in oral microbial ecology. Annual Review of Microbiology 29, 19-44.

Gibbons, R. J., Berman, K. S., Knoettner, P. \& Kapsimalis, B. (1966). Dental caries and alveolar bone loss in gnotobiotic rats infected with capsule forming streptococci of human origin. Archives of Oral Biology 11, 549-560.

Guggenheim, B., Regolati, B. \& MuhlemanN, H. R. (1972). Caries and plaque inhibition by mutanase in rats. Caries Research 6, 289-297.

HAMADA, S. \& ToRII, M. (1978). Effect of sucrose in culture media on the location of glucosyltransferase of Streptococcus mutans and cell adherence to glass surfaces. Infection and Immunity 20, 592-599.

Hojo, S., Higuchi, M. \& ARaya, S. (1976). Glucan inhibition of diffusion in plaque. Journal of Dental Research 55, 169.

JANDA, W. M. \& Kuramitsu, H. K. (1976). Regulation of extracellular glucosyltransferase production and the relationship between extracellular and cell-associated activities in Streptococcus mutans. Infection and Immunity 14, 191-202.

JANDA, W. M. \& Kuramitsu, H. K. (1978). Production of extracellular and cell-associated glucosyltransferase activity by Streptococcus mutans during growth on various carbon sources. Infection and Immunity 19, 116-122.

Keene, J. H., Shklair, I. L., Mickel, G. J. \& Wirthlin, M. R. (1977). Distribution of Streptococcus mutans biotypes in five human populations. Journal of Dental Research 56, 5-10.

Keevil, C. W., Hough, J. S. \& Cole, J. A. (1979). Regulation of respiratory and fermentative modes of growth of Citrobacter freundii by oxygen, nitrate and glucose. Journal of General Microbiology 113, 83-95.

KogA, T. \& Inoue, M. (1978). Cellular adherence, glucosyltransferase adsorption and glucan synthesis of Streptococcus mutans AHT mutants. Infection and Immunity 19, 402-410.

KulKa, R. G. (1956). Colorimetric estimation of ketopentoses and ketohexoses. Biochemical Journal 63, 542-549.

LENNOX, E. S. (1955). Transduction of linked genetic characters of the host by bacteriophage P1. Virology 1, 190-206.

MCCABE, M. M. \& SMith, E. E. (1973). Origin of the cell-associated dextran sucrase of Streptococcus mutans. Infection and Immunity 7, 829-838.

Montville, T. J., Cooney, C. L. \& Sinskey, A. J. (1977). Distribution of dextransucrase in Streptococcus mutans and observations on the effect of soluble dextran on dextransucrase activities. Infection and Immunity 18, 629-635.

Nalbandian, J., Freedman, M. L., Tanzer, J. M. \& LovelaCe, J. M. (1974). Ultrastructure of mutants of Streptococcus mutans with reference to agglutination adhesion and extracellular polysaccharide. Infection and Immunity 10, 1170-1179.

Robrish, S. A., ReID, W. \& KRICHEVSKY, M. I. (1972). Distribution of enzymes forming polysaccharide from sucrose and the composition of extracellular polysaccharide synthesised by Streptococcus mutans. Applied Microbiology 24, 184-190.

Schachtele, C. F., Harlander, S. K. \& Germaine, G. R. (1976). Streptococcus mutans dextransucrase: availability of disaggregated enzyme after growth in a chemically defined medium. Infection and Immunity 13, 1522-1524. 